\title{
Biodiesel Production from Jatrophacurcas Linnaeus: A Review
}

\author{
Manish Awana ${ }^{1}$, Piyush Shori ${ }^{2}$, Saurav Suman ${ }^{3}$, Akash Maheshwari $^{4} \&$ Devender Sharma ${ }^{5}$ \\ 1,2,3,4 Final Year B Tech (Aero) Students, \\ ${ }^{5}$ Professor and HOD (Aero Engg) \\ 1,2,3,4,5 Manav Rachna International Institute of Research and Studies, Faridabad, 121004
}

\begin{abstract}
Since fossil fuels are getting depleted day by day, by virtue of which there exists an increasing urge for the past two decades to produce biodegradable, non-toxic fuel. With added advantage of $\mathbf{7 8 . 5}$ percent less carbon dioxide andcarbon monoxide emission than petroleum diesel, biofuel could prove to be the future of aviation fuel.Also, industrial processing can extract biodiesel from both vegetable and an imal fats.A multipurpose plant, Jatropha Curcas Linnaeus which boasts of high content of oil in its seeds can be used to produce biodiesel with the help of different types of che mical processes. The emphasis of this review is to analyse $p$ roduction methods of biodiesel on large scale, relevant com bustion properties of this fuel and have insights about Jatro pha Curcas Linnaeus plant.
\end{abstract}

Keywords: Biodiesel, Transesterification, Pyrolysis.

\section{INTRODUCTION}

As fossil fuels are getting depleted day by day, by virtue of which there is a continuous research going on for the production of renewable sources of fuel from vegetable oils and animal fats. Comprised of mono-alkyl esters of long fatty acids, biofuels are derived from animal fats or vegetable oils.(Demirbas, 2000; Kinney and Clemente, 2005; Wilson et al., 2005). These fuels could be either in the form of animal fats or vegetable oils and they are converted into biodiesel using chemical or natural processes. With little modification, these wastes from animals and plants could be utilized as fuels. In fact, chemicals and fibers essential in daily life could also be produced with modification in these organic wastes. The comparison in the carbon content and its emission upon combustion lays the foundation stone for the difference between fossil fuels and biofuels. Modern engines that are manufactured today are made to operate on a vast variety of fuels, such as diesel, petrol,or gas as their primary source of fuel. Diesel engines running on biofuel almost provide same power output with slightly lower thermal efficiency, when compared to diesel engine running on fossil diesel. (Makkar et al., 1997; Pramanik, 2003; Agarwal and Agarwal, 2007; Tiwari et al., 2007). Also, there is a stark similarity between diesel fuel and biofuels in composition, hence this eliminates the need to modify engines to run on biofuels. Also, when compared to petrol engines, diesel engines produce the same amount of work with comparatively less consumption of fuel. Biodiesel is gaining popularity these days due to it's carbonneutral source of nature. This liquid fuel can be obtained by processing vegetable oils chemically and then modifying its properties to match its performance with diesel. Biodiesel have similar characteristics like that of diesel(Agarwal, 2007). Africa and Asia being the net importers of vegetable oil, have identified Jatropha Curcas as their latest crop for the nations to increase their own renewable source of energy. With the increase in interest in biofuels globally, the need for national governments to intervene and device mechanisms to harness the value of the rapid paced industry and benefit from the increasing international trade in biofuels. Africa's initiative to utilise Jatropha to expedite the production of biofuels could place the continent as an global trader and distributor of biodiesel, hence increasing the political and economic leverage in the global society. Leading multinational corporations across the world, especially from China, India, Europe and Scandinavia have already started the hoard to acquire African land to start commercialise Jatropha productions. Telecom giants such as GSMA, Ericsson and MTN also don't want to leave this opportunity and have started their bids to invest in promoting the use of Jatropha biofuel to prove beneficial for the base stations of the cellular networks in this developing technical market across the globe (Katembo and Gray, 2007).

The plant family, Euphorbiaceae, infamous for hosting many plants which object with the Geneva Convention on chemical warfare, also hosts the origin of Jatropha Curcas Linnaeus plant. This plant was first found in Mexico and was then introduced to Africa and Asia as a hedge plant Portuguese traders. The word Jatropha is extracted from the Greek word Jatros meaning doctor and trophe meaning food, which point towards medical applications, and that is why Jatropha finds traditional uses for medical purposes. Also, Jatropha is an ideal plant for small farmers since it is a grown as a shrub and can sustain itself on poor soils in the areas of less rainfall (250 mm annually)(Sarin et al.,2007; Foidl et al., 1996; Gressel, 2008). Owing to its ability to grow well in relatively less quality soil, it may also prove to help reclaim the already degraded land and preventing soil erosion. On an average, each Jatropha plantation is able to produce about five kilograms of seeds annually under optimal conditions. It has a long productive which lasts for a period of around 30 - 50 years (Banapurmath et al., 2008; Tamalampundi et al., 2008). 


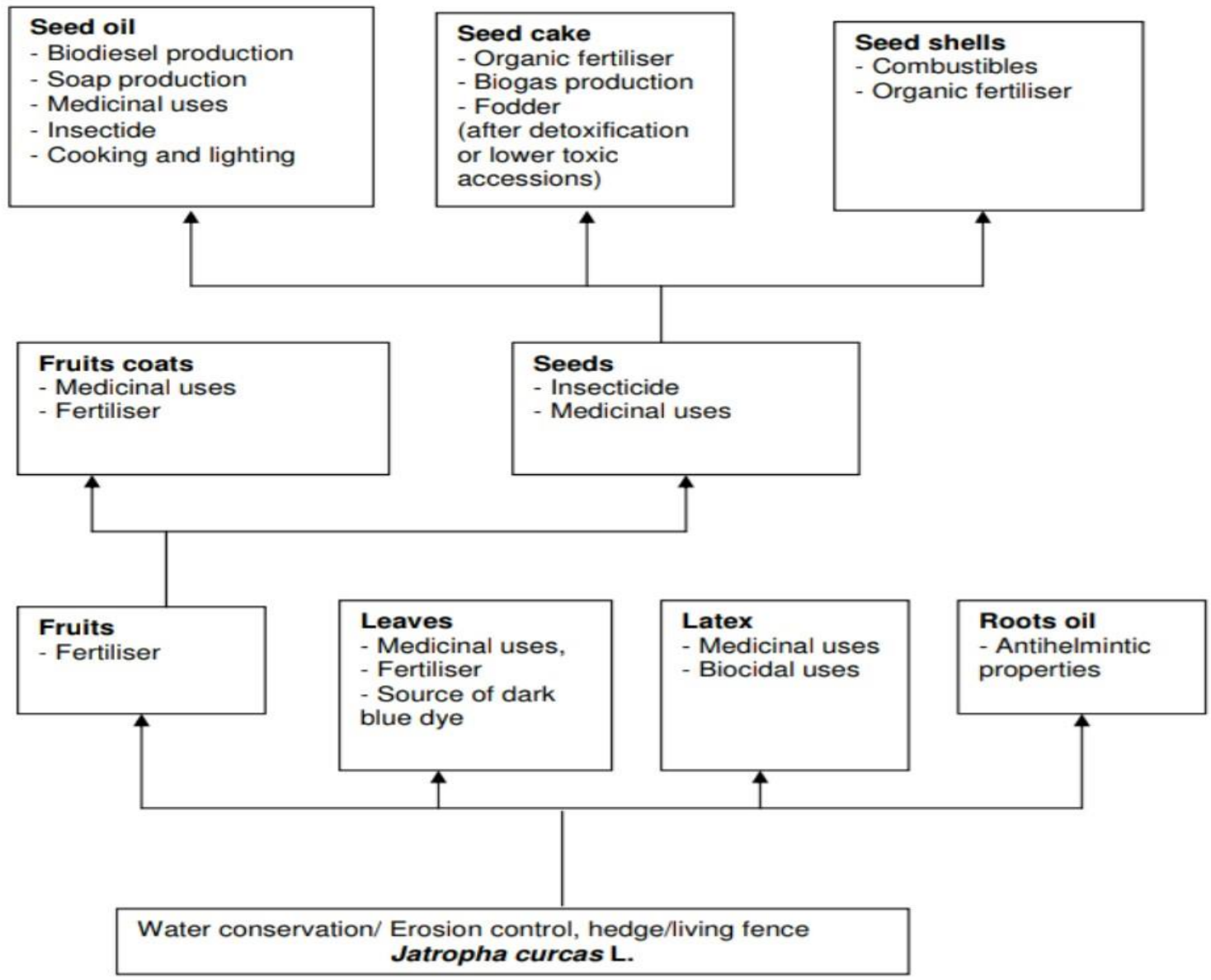

Figure 1. The various uses of $J$. curcas components (adapted from Jones and Miller, 1991).

Various benefits are also extracted from the frond, bark and the leaves of this plant, are illustrated in figure 1 above and Table 1 below tabulates major benefits and drawbacks of J. curcas production. Out of many agronomic claims about Jatropha Curcas, only a handful are scientifically sustained.

Table 1. The potential advantages and disadvantages of $J$. curcas L. plant.

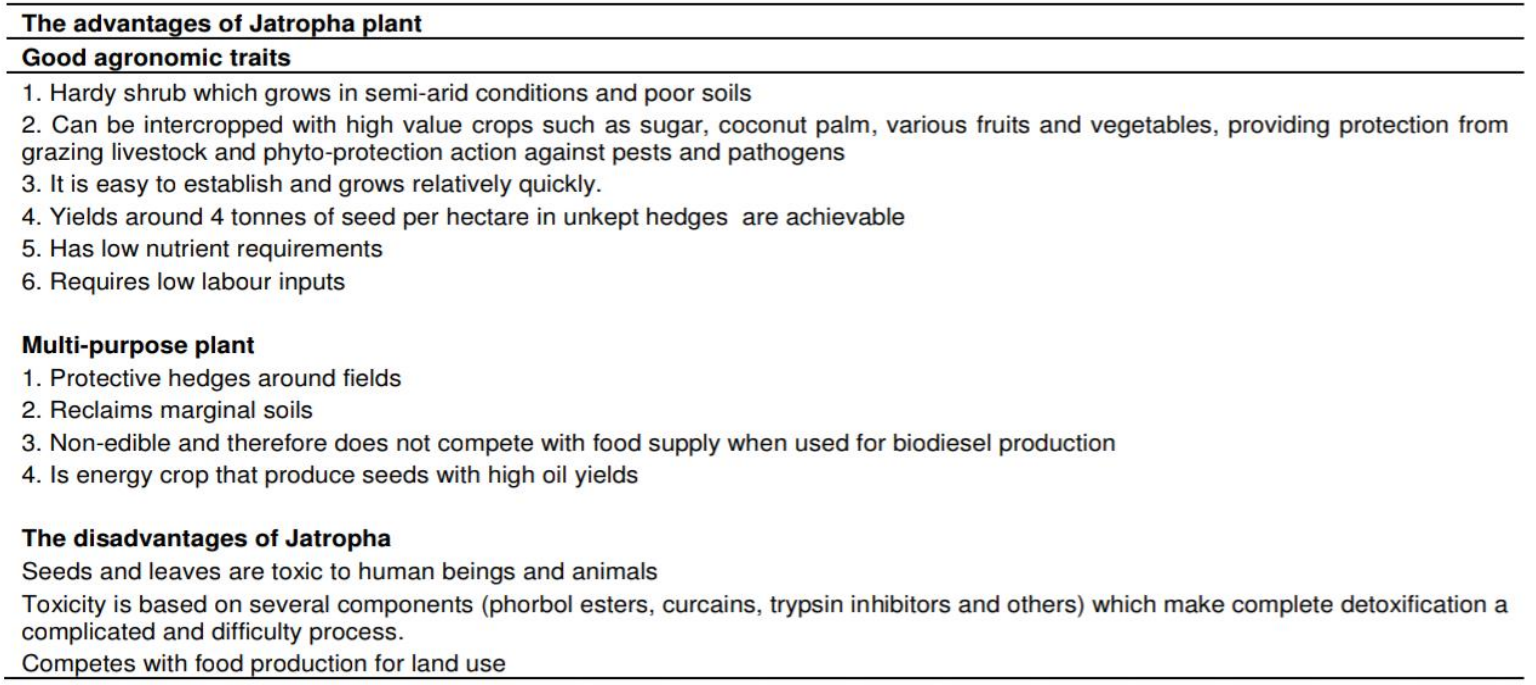


Table 2. Specifications of the seed of the seed oil of J. curcas (Foidl et al., 1996; Tamalampundi et al., 2008).

\begin{tabular}{lccc}
\hline Variable & Variety Caboverde & Variety Nicaragua & Variety Nigeria \\
\hline Colour & Light yellow & Light yellow & Light yellow \\
\hline Saponification number $(\mathrm{mg} / \mathrm{g})$ & 192 & 190 & 199 \\
Viscosity at $30^{\circ} \mathrm{C}(\mathrm{cSt})$ & 39 & 37 & 17 \\
Free fatty acids $(\%$ weight$)$ & $0.3-0.4$ & $0.6-1.3$ & 1.8 \\
Unsaponifiable $(\%$ weight) & 1.1 & 0.8 & 0.8 \\
lodine number & 95 & 107 & 105 \\
Acid value & - & - & 3.5 \\
Specific gravity $\left(25^{\circ} \mathrm{C}\right)$ & - & - & 0.92 \\
\hline
\end{tabular}

\title{
PROCESSING TECHNIQUES
}

\section{Pyrolysis (Thermal Cracking)}

The process of converting one substance into another in the presence of heat without air (Oxygen), or with heat along with a catalyst, which leads to the formation of a wide range of small molecules, is termed as pyrolysis.

Extensive studies have been carried out upon the pyrolysis of Jatropha seed oil has led to the conclusion that it leads to the production of alkenes, alkanes, alkadienes, carboxylic acids and aromatics in varying proportions (Ma and Hanna,1999; Alencar et al., 1983; Peterson, 1986).

\section{Transesterification (Alcoholysis)}

The synthesis of an oil (triglyceride) or a fat with an alcohol to produce fatty acid alkyl esters, glycerol and methyl and ethyl esters is known as transesterification.

The process is shown as below:

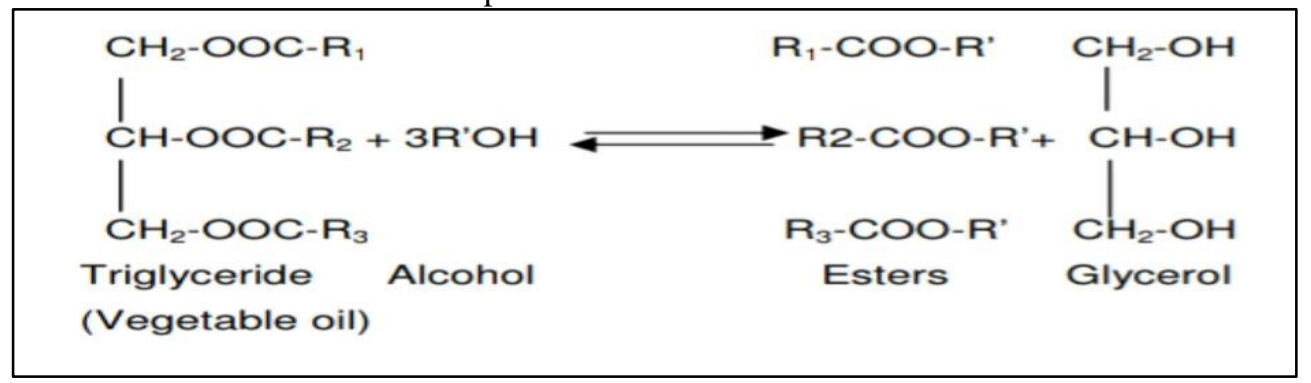

In industries, vegetable oils are heated with excess alcohol under varying conditions in the presence of catalysts such as Sodium Hydroxide to produce the biofuel in large quantity. Excess of alcohol is used in order to shift the reaction's equilibrium to the products side because the reaction is reversible. Most widely used alcohols in the transesterification process are ethanol, methanol, butanol, propanol and amyl alcohol. Such reactions are mostly catalysed by an enzyme, either acidic or basic in order to increase the rate of reaction and improve the yield. Commercially, alkali based catalysts are used more commonly since they make the transesterification process much faster than acid catalysed reactions (Ma and Hanna, 1999; Ranganathan et al., 2008; Agarwal and Agarwal, 2007). Due to the drastic changes in viscosity of vegetable oils due to transesterification, the glycerol has to be removed and thus brings the viscosity of the remaining product similar to that of fossil fuels.

\section{EFFECT OF CATALYST}

A catalyst is a chemical reagent which helps to accelerate a chemical reaction and make it feasible. In case of the process of transesterification, an alkali/aicd makes the reaction faster and is thus used as a catalyst in the reaction.

\begin{abstract}
Alkali Catalyst
It has been observed experimentally that often the transesterification reactions which are catalysed by alkalis are more faster than those catalysed by acid catalysts.(Ma and Hanna, 1999; Ranganathan et al.,2008; Agarwal, 2007; Marchetti et al., 2007). Sodium hydroxide or potassium hydroxide is used as alkaline catalyst with ethanol or methanol as well as the vegetable oil. The basic catalyst concentration in the range of $0.5-1 \%$ by weight yield $94-99 \%$ conversion of most vegetable oils into esters. . The process is energy intensive, as the alkaline catalyst needs to be separated from the final product, the recovery of glycerol becomes difficult. Also, the wastewater produced requires treatment and the level of water and free fatty acids interfere with the reaction. Soap formation takes place due to free acid and water contamination and due to the same reason, the process of separation becomes a challenging process to complete (Fukuda et al., 2001; Barnwal and Sharma, 2005).
\end{abstract}




\section{Acid Catalyst}

The alternate method to engender biodiesel is to use alcohol with the animal fats and an acid. The most commonly used acidic catalyst in this process is Sulphuric Acid. If higher free fatty acid or water is present in the animal fat then, acid cataly st is used. Despite of the high yields, another risk always looms in the industrial process, which is the time taking nature of the reaction due to the corrosive nature of the acid (Freedman et al., 1984). Some authors has enunciated that the reactions are slow, needing typically temperatures above $373^{\circ} \mathrm{F}$ and more than 3 hours to fully complete the conversion.(Meheret al., 2006).

PROPERTIES OF JATROPHA BIOFUEL

Table 3: Juxtaposition of the different technologies to produce biodiesel.

\begin{tabular}{lll}
\hline Variable & Alkali catalysis & Acid catalysis \\
\hline Reaction temp $\left({ }^{\circ} \mathrm{C}\right)$ & $60-70$ & $55-80$ \\
Free fatty acid in raw materials & Saponified products & Esters \\
Water in raw materials & Interference with reaction & Interference with reaction \\
Yields of methyl esters & Normal & Normal \\
Recovery of glycerol & Difficult & Difficult \\
Purification of methyl esters & Repeated washing & Repeated washing \\
Production cost of catalyst & Cheap & Cheap \\
\hline
\end{tabular}

Table 4: Properties of jatropha oil, jatropha biodiesel and fossil diesel Fuel (Kamman and Phillip, 1985; Matsumoto et al.,2001; Ban et al., 2001).

\begin{tabular}{lccccc}
\hline \multirow{2}{*}{ Property } & \multirow{2}{*}{ J. oil } & \multirow{2}{*}{ J. biodiesel } & \multirow{2}{*}{ Diesel } & \multicolumn{2}{c}{ Biodiesel standards } \\
\cline { 5 - 6 } & & & & AST D 6751-02 & DIN EN 14214 \\
\hline Density $\left(15^{\circ} \mathrm{C}_{\mathrm{kgm}} \mathrm{kgm}^{-3}\right)$ & 940 & 880 & 850 & - & $860-900$ \\
Viscosity $\left(\mathrm{mm}^{2} \mathrm{~s}^{-1}\right)$ & 24.5 & 4.8 & 2.6 & $1.9-6.0$ & $3.5-5.0$ \\
Flash point $\left({ }^{\circ} \mathrm{C}\right)$ & 225 & 135 & 68 & $>130$ & $>120$ \\
Pour point $\left({ }^{\circ} \mathrm{C}\right)$ & 4 & 2 & -20 & - & - \\
Water content $(\%)$ & 1.4 & 0.025 & 0.02 & $<0.03$ & $<0.05$ \\
Ash content $(\%)$ & 0.8 & 0.012 & 0.01 & $<0.02$ & $<0.02$ \\
Carbon residue $(\%)$ & 1.0 & 0.20 & 0.17 & - & $<0.30$ \\
Acid value $\left(\mathrm{mgKOHg}^{-1}\right)$ & 28.0 & 0.40 & - & $<0.80$ & $<0.50$ \\
Calorific value $\left(\mathrm{MJkg}^{-1}\right)$ & 38.65 & 39.23 & 42 & - & - \\
\hline
\end{tabular}

\section{APPLICATION OF BIODIESEL IN COMBUSTION ENGINES}

Since vegetable oils have high viscosity,so this property of jatropha oil creates a problem in pumping and spraying characteristics when it is used in combustion engines. For compression ignition engines, biodiesel can be blended with fossil diesel in order to create a new bled of biodiesel or it can also be used in its purest composition. Since the biodiesel has very similar attributes when compared to mineral diesel, because of which compression ignition engines require very minute modification or no modifications. The various advantages and disadvantages of biodiesel are given in table 5. Without detoxification jatrophacurcas oil cannot be used for comestible purposes, making its use as a energy source for fuel production very usefuel. During second world war, biodiesel extracted from jatrophacurcas oil was used as a substitute for diesel fuel in madagascar, cape verde and benin. Early engine tests were done in thailand with jatrophacurcas oil which depicted satisfactory performance of the engine. (Gubitz et al., 1999; Recep et al.,2000). 
Table 5: Advantages and Disadvantages of biodiesel fuel.

\begin{tabular}{l}
\hline Advantages of biodiesel \\
\hline 1. Provides a domestic, renewable energy supply. \\
2. Biodiesel is carbon neutral because the balance between the amount of $\mathrm{CO}_{2}$ emissions and the amount of $\mathrm{CO}_{2}$ absorbed by the \\
plants producing vegetable oil is equal. \\
3. Biodiesel can be used directly in compression ignition engines with no substantial modifications of the engine. \\
4. Blending of biodiesel with diesel fuel increases engine efficiency. \\
5. The higher flash point of biodiesel makes its storage safer. \\
6. Biodiesel is non-toxic. \\
7. Biodiesel degrades four times faster than diesel. \\
8. $\mathrm{CO}, \mathrm{CO}_{2}$ and UBHC, PAH, soot and aromatics emissions are reduced in biodiesel and its blends than in fossil diesel because \\
biodiesel is oxygen in structure and it burns clearly all the fuels. \\
9. It is biodegradable. \\
Disadvantages of biodiesel \\
1. More expensive due to less production of vegetable oil. \\
2. Blends of biodiesel above $20 \%$ can cause engine maintenance problems and even sometimes damage the engine in the long term.
\end{tabular}

\section{CONCLUSION}

From being used traditionally for medicinal uses to being used to prevent soil erosion, Jatropha Curcas Linnaeus is also used as a source of an oil that has the potential to be converted into biodiesel. Also, Jatropha is also said to be beneficial against the use of omnipresent greenhouse effect, creating auxiliary earnings for the rural individuals, and provide a vital source of renewable energy globally. Researchers enunciated that biodiesel contains lower aromatics and extra oxygen molecules when compared to base fuel diesel.(Arunkumar et al.,2019;Kavitha et al.,2019).The presence of lower sulphur content in biodiesel leads to soot production in fuel which ultimately results into lower smoke emission(Monirul et al., 2016; Arunkumar et al., 2019;Kandasamy et al., 2019). The lower carbon molecule in biodiesel is another reason for this(Khan et al., 2018;Dhamodaran et al., 2017;Kandasamy et al., 2019).Biodiesel has the properties which can make it an alternative to fossil diesel owing to its environmental benefits such as fewer carbon emission and due to the gospel that it is extracted from renewable resources, Jatropha is a auspicious source of biodiesel since its seeds can hold considerable amount of oil and the species has good attribute.In India, there are enormous potentiality for the extraction of biofuels from Jatropha Curcas as they are found in wastelands across India.

\section{REFERENCES}

[1] Agarwal D, Agarwal AK (2007). Performance and emission ch aracteristics of a Jatropha oil blends in a combustion engin e. Int. J. Appl. Therm. Eng., 27: -23.-2314.

[2] Agarwal AK (2007). Biodiesel for varrious types of combustio n engines. Prog. Energ. Combust. Sci., 33: 233-271.

[3] Alencar JW, Alves PB, Craveiro AA (1983). Pyrolysis techni que of vegetable oils. J. Agric. Food Chem., 31: 1268-1270.

[4] Arunkumar, M.; Kannan, M.; Murali, G. Experimental studies on engine performance and emission characteristics using casto $\mathrm{r}$ biodiesel as fuel in CI engine. Renew. Energy 2019, 131, 73 7-744.

[5] Banapurmath NR, Tewari PG, Hosmath RS (2008).DI combust ion engine performance when operated on Honge, Jatropha an d sesame oil methyl esters. Renew. Energ. 33: 1982-1988.

[6] Barnwal BK, Sharma MP (2005). Possibility of biodiesel pro duction from vegetable oils in India. Renew. Sustain. Energ., 9: $363-378$.
[7] Ban K, Kaieda M, Matsumoto T, Kondo A, Fukuda H (2001) Whole cell biocatalyst for biodiesel fuel production utilising Rhizopus oryzae cells immobilised within biomass support pa rticles. Biochem. Eng., 8:39-43.

[8] Demirbas A (2000). Conversion of biomass using glycerine to liquid fuel for blending gasoline as alternative engine fuel. En ergy Convers. Manage. 41: 1741-1748.

[9] Dhamodaran, G.; Krishnan, R.; Pochareddy, Y.K.; Pyarelal, H. M.; Sivasubramanian, H.; Ganeshram, A.K.A comparative stud $\mathrm{y}$ of combustion, emission, and performance characteristics of rice-bran-, neem-, and cottonseed-oil biodiesels with varying d egree of unsaturation. Fuel 2017, 187, 296-305.

[10] Foidl N, Foidl G, Sanchez M, Mittelbach M, Hackel S (1996). Jatropha curcas L. as a source for the production of diesel fu el in Nicaragua. Bioresour. Technol., 58: 77-82.

[11] Fukuda H, Kondo A, Noda H (2001). transesterification proces s used to produce biofuel. J. Biosci. Bioeng., 92: 405-416.

[12] Freedman B, Pryde EH, Mounts TL (1984). Variables affectin $\mathrm{g}$ the yields of fatty esters from transesterified vegetable oils. JAOCS. 61: 1638-1643

[13] Gressel J (2008). Transgenics are imperative for biofuel cropsReview. Plant Sci. 174: 246-263.

[14] Gubitz GM, Mittelbach M, Trabi M (1999). Utilization of jatr opha curcas in tropical region. Jatropha curcas L. Bioresour. T echnol., 67: 73-82.

[15] Jones N, Miller JH (1991). Jatropha curcas for Problematic Sit es. Land Resources series 1: 40-43.

[16] Kandasamy, S.K.; Selvaraj, A.S.; Rajagopal, T.K.R. Experimen tal investigations of ethanol blended biodiesel fuel on automoti ve diesel engine performance, emission and durability characte ristics. Renew. Energy 2019,141, 411-419.

[17] Kavitha, M.S.; Murugavelh, S. Optimization and transesterifica tion of sterculia oil: Assessment of engine performance, emissi on and combustion analysis. J. Clean. Prod. 2019, 234, 11921209.

[18] Kinney AJ, Clemente TE (2005). Modifying soybean oil for e nhanced performance in biodiesel blends. Fuel Process Techno 1. 86: 1137-1147. Kamman Jr KP, Phillip AI (1985). Sulfurize d vegetable oil products as lubricants additives. J. Am. Oil Ch em. Soc., 65: 883-885.

[19] Katembo BI, Gray PS (2007). Africa, Seeds Biofuel. J. Multid isciplinary Res. 1: 1-6.

[20] Khan, K.; Kumar, G.; Sharma, A.K.; Kumar, P.S.; Mandal, C.; Chintala, V. Performance and emission characteristics of a die sel engine. Biofuels 2018, 9, 53-60.

[21] Makkar HPS, Becker K, Sporer F, Wink M (1997). Research on the nutitional value and various toxic constituents in jatrop ha curcas. J. Agric. Food Chem., 45: 3152-3157.

[22] Ma F, Hanna MA (1999). Biofuel Production: a review. Biore sour. Technol., 70: 1-15. 
[23] Marchetti JM, Miguel VU, Errazu AF (2007). Various metho ds available for biofuel production. Renew. Sustain. Energ., 11 : 1300-1311.

[24] Meher LC, Sagar DV, Naik SN (2006). Transesterification pro cess for the production of biofuel. A review. Renew. Sust. En ergy Rev. 10: 248-268.

[25] Matsumoto T, Takahashi S, Kaieda M, Ueda M, Tanaka A, Fa kuda H,Kondo A (2001). Yeast whole-cell biocatalysts constru cted by intracellular overproduction of Rhizopus oryzae lipase are applicable to biofuel production. Appl. Microbiol. Biotechn ol., 57: 4-11.

[26] Monirul, I.M.; Masjuki, H.H.; Kalam, M.A.; Mosarof, M.H.; Z ulkifli, N.W.M.; Teoh, Y.H.; How, H.G.Assessment of perform ance, emission and combustion characteristics of palm, jatroph a and Calophyllum inophyllum biodiesel blends. Fuel 2016, 18 1, 985-995.

[27] Pramanik K (2003). characteristics and use of biodiesel fuel in various combustion engines. Int. J. Renew. Energy. 28:239-2 48.

[28] Peterson CL (1986). Vegetable oils used for biofuel production Status and Research Prior.. Trans. ASAE. 29: 1413-1422.

[29] Ranganathan SV, Narasimhan SL, Muthukumar K (2008). An Survey of enzymatic production of biofuel. Bioresour. Technol ., 99: 3975- 3981

[30] Recep A, Selim C, Huseyin SY (2000). The potential of using biofuel in various combustion engines. Int. J. Energy. Conve rs. Manage., 42: 529-538.

[31] Sarin R, Sharma M, Sinharay S, Malhotra RK (2007). Jatroph a-Palm biodiesel blends: An optimum mix for Asia. Fuel 86: 1 365-1371. Shay EG (1993). Biofuel from vegetable oil: Bioma ss Bioenerg. 4: 227-242.

[32] Tamalampundi S, Talukder MR, Hama S, Numata T, Kondo A, Fukuda H (2008). Enzymatic production of biodiesel from Jatropha oil: A comparative study of immobilised-whole cell a nd commercial lipases as a biocatalyst. Biochem. Eng., J. 39: 185-189.

[33] Tomasevic AV, Marinkovic SS (2003). Methanolysis of used o ils. Fuel Process Technol. 81: 1-6.

[34] Tiwari AK, Kumar A, Raheman H (2007). Optimised process for production of diesel fuel from jatropha with high fatty aci d. Biomass Bioenerg. 31: 569-575

[35] Wilson SC, Mathews M, Austin G, von Blottnitz H (2005). R eview of current status of biofuel related activity in south afric a. Report for the town of Cape Town, South Africa p. 76. 